\title{
PROVENANCE EVOLUTION DURING ASSEMBLY OF THE ACADIAN/NEOACADIAN OROGEN: DETRITAL ZIRCON DATA FROM THE DEVONIAN OF NEW YORK
}

SELLECK, Bruce ${ }^{1}$, VER STRAETEN, Charles ${ }^{2}$, CHIARENZELLI, Jeffrey R. ${ }^{3}$ and HOLZMAN, Emily ${ }^{1}$, (1)Department of Geology, Colgate University, Hamilton, NY 13346, (2)New York State Museum \& Geological Survey, 3140 Cultural Education Center, Albany, NY 12230, (3)Department of Geology, St. Lawrence University, Canton, NY 13617, bselleck@colgate.edu

Support: New York State Museum; Boyce Fund, Colgate University

\section{Colgate}


Foreland basin records orogenic history

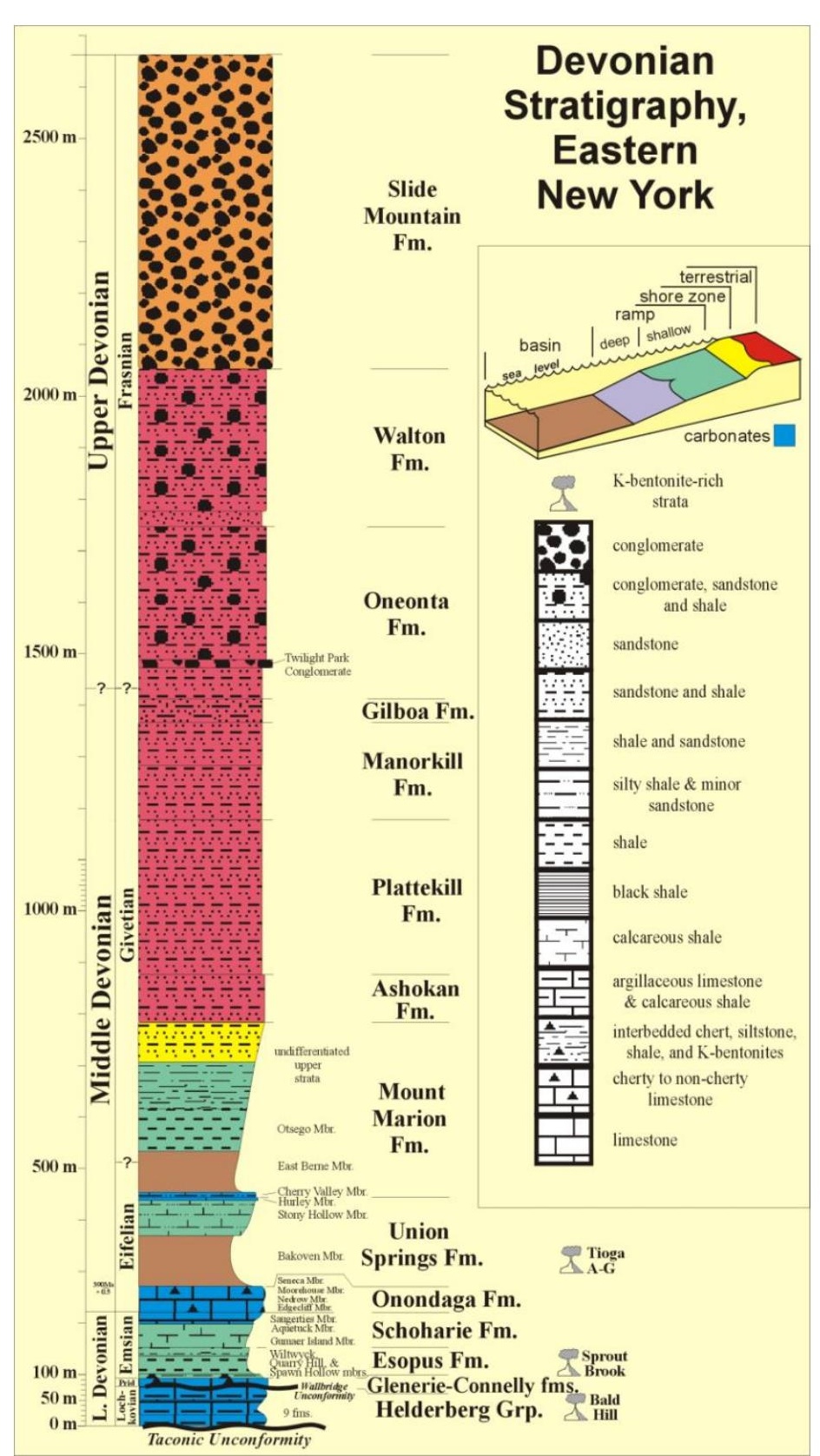




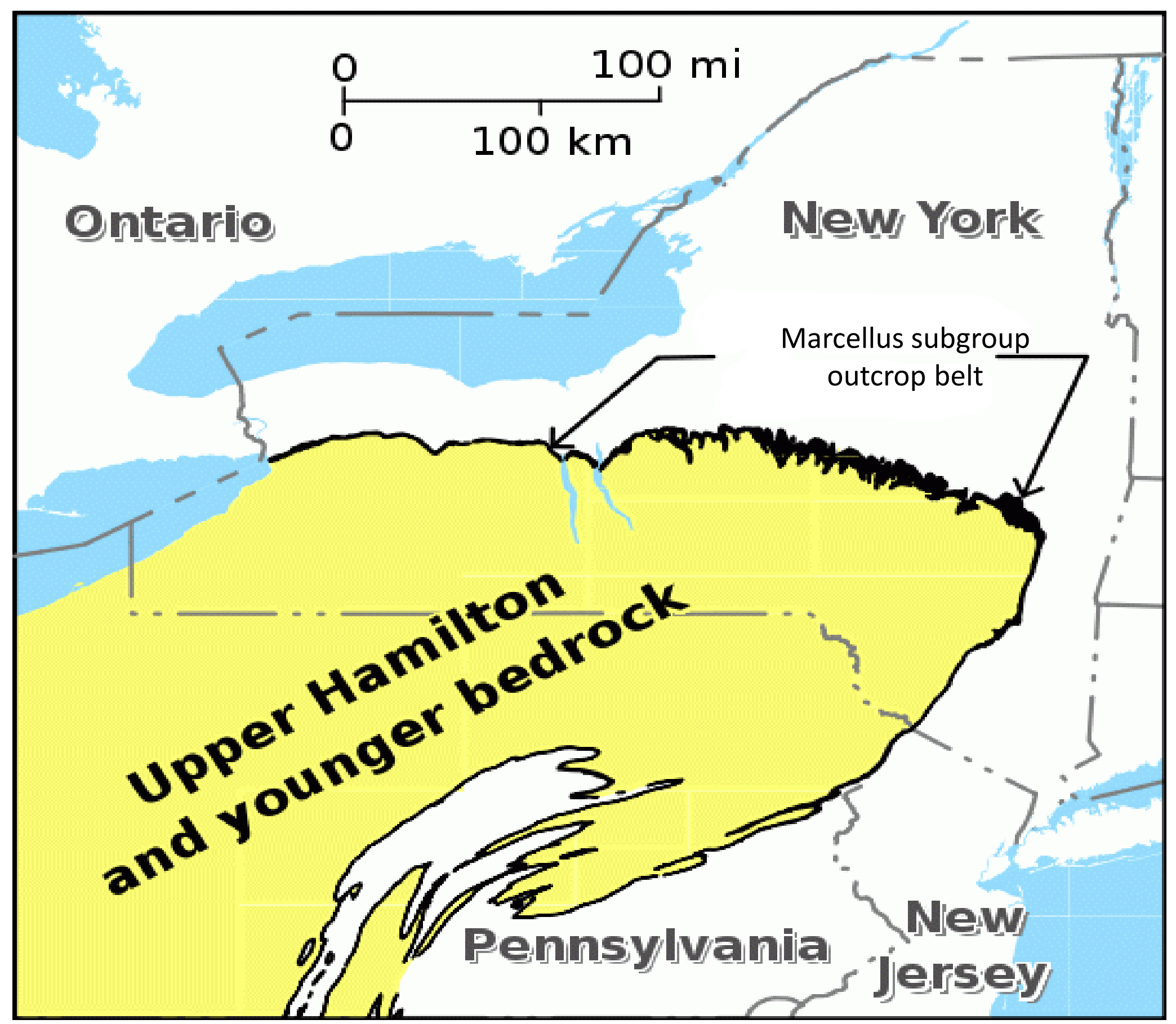

modified after Steven Schimmrich hudsonvalleygeologist.blogspot.com 


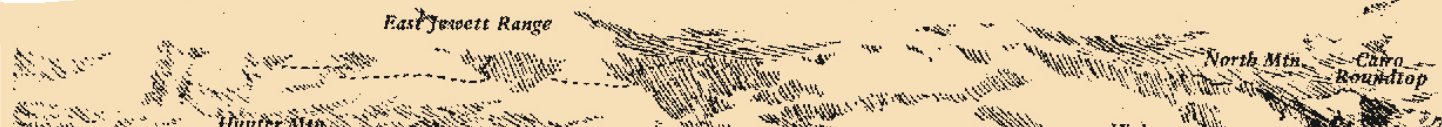

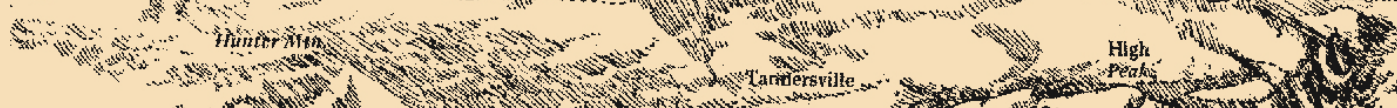

(n)

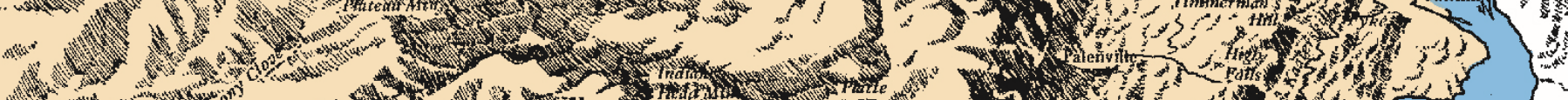

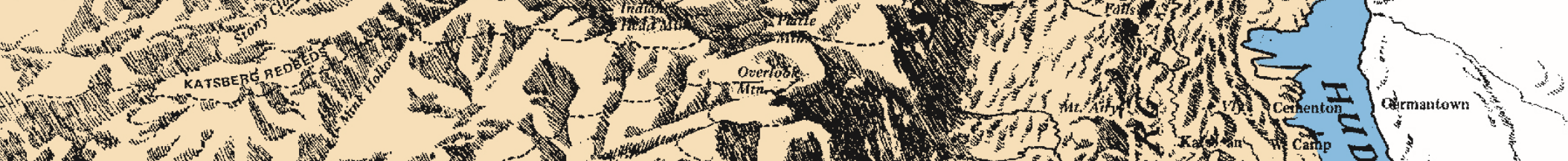
1.4.

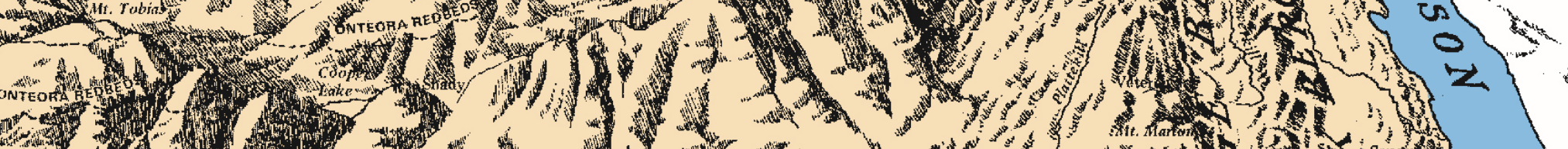

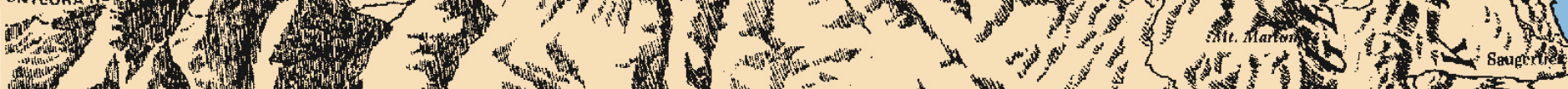

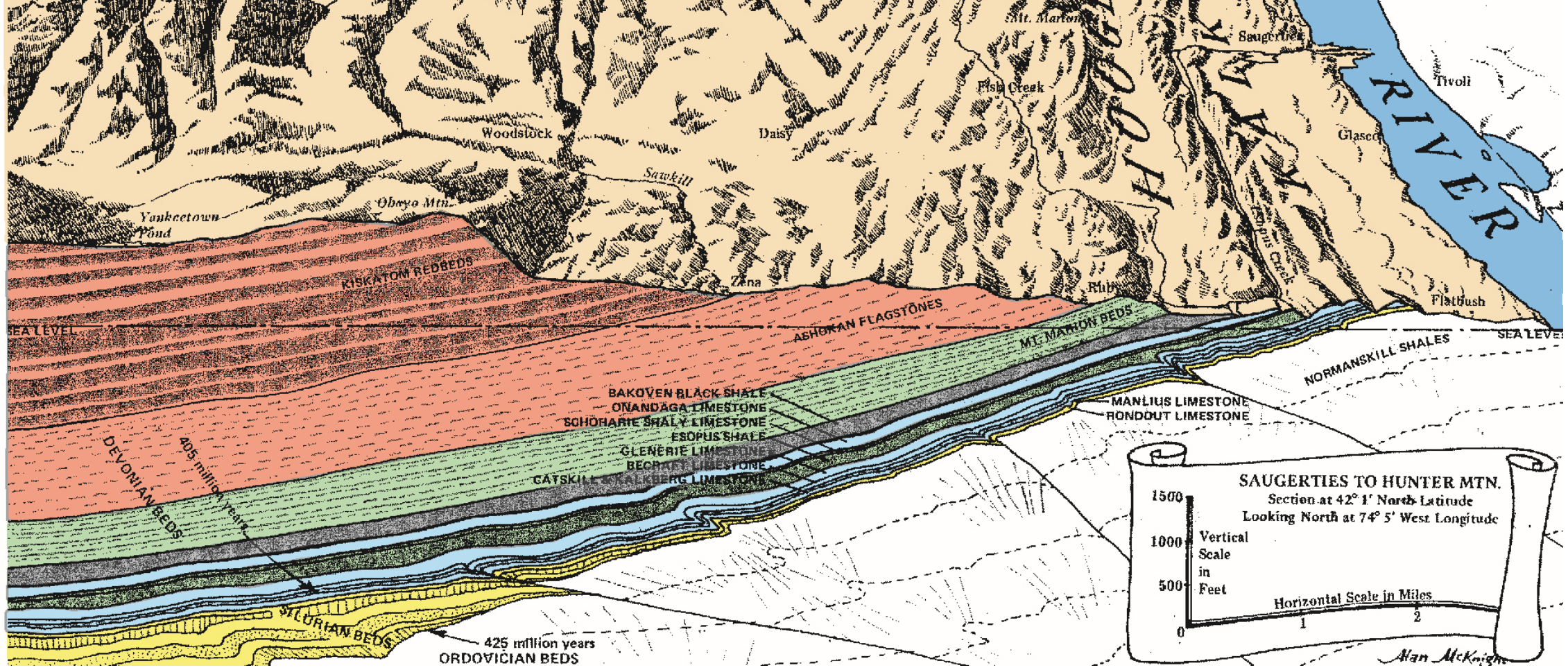



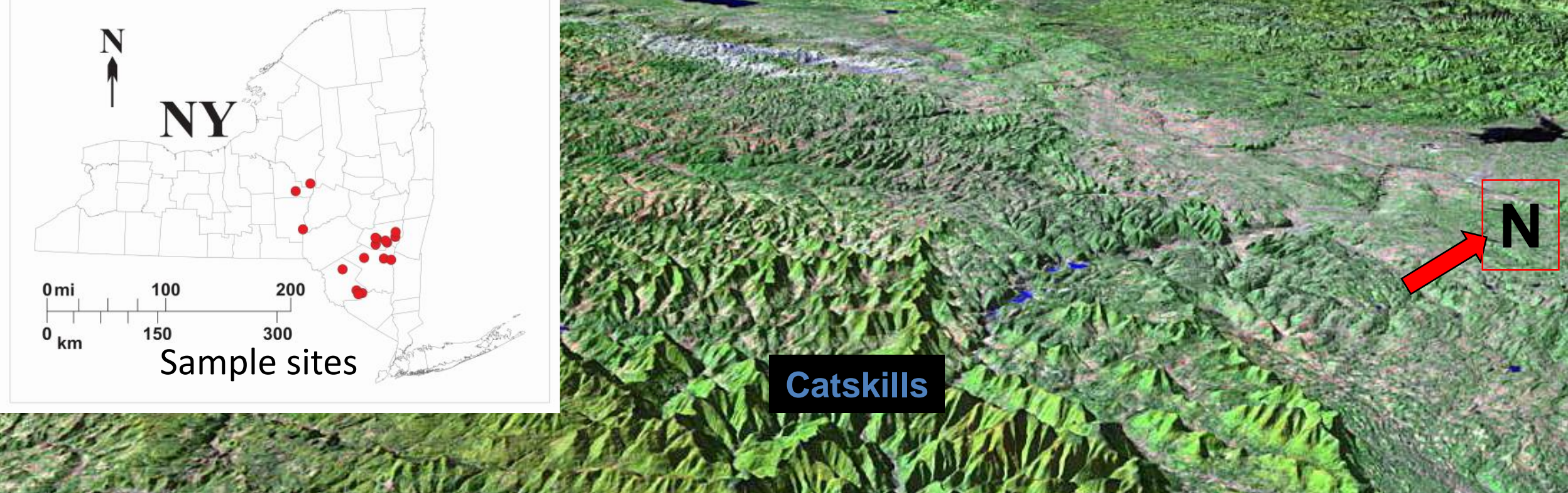

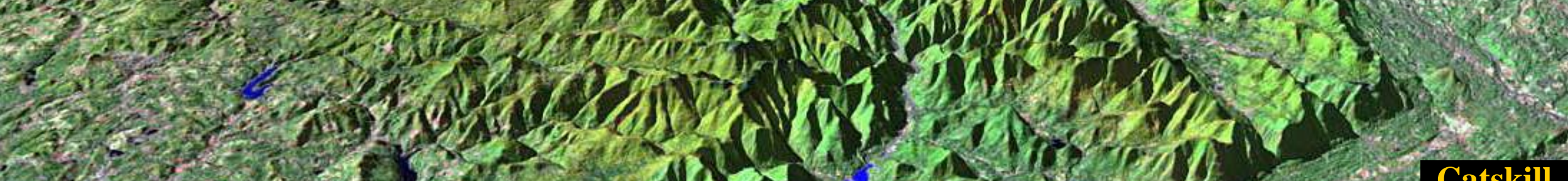
153

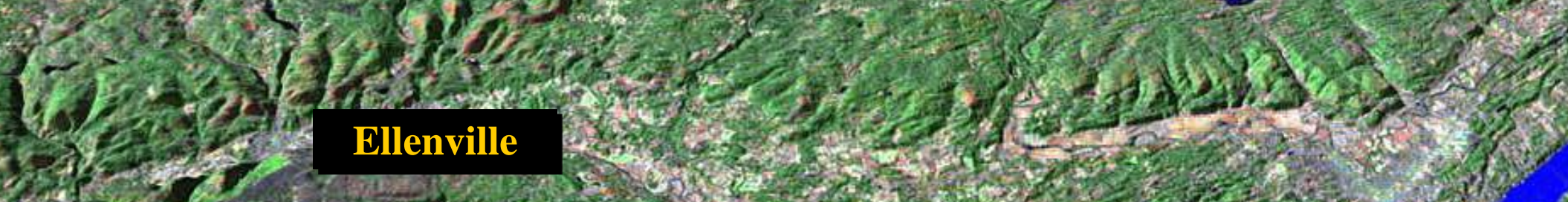

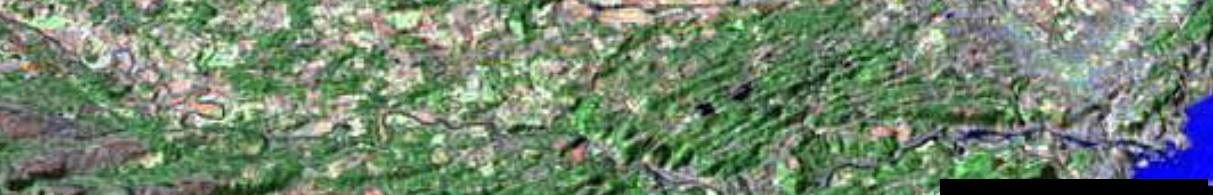

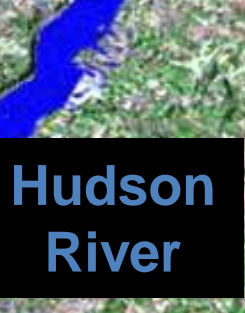

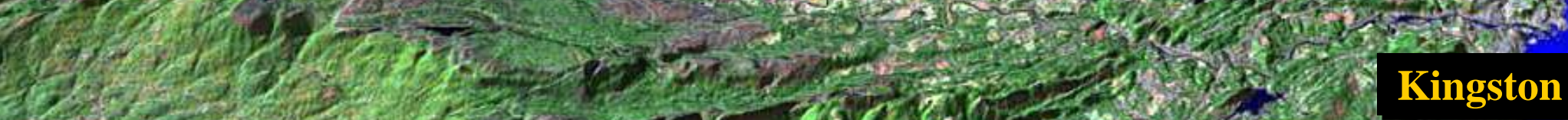
(a) (2) 


\section{Stratigraphic distribution of samples}

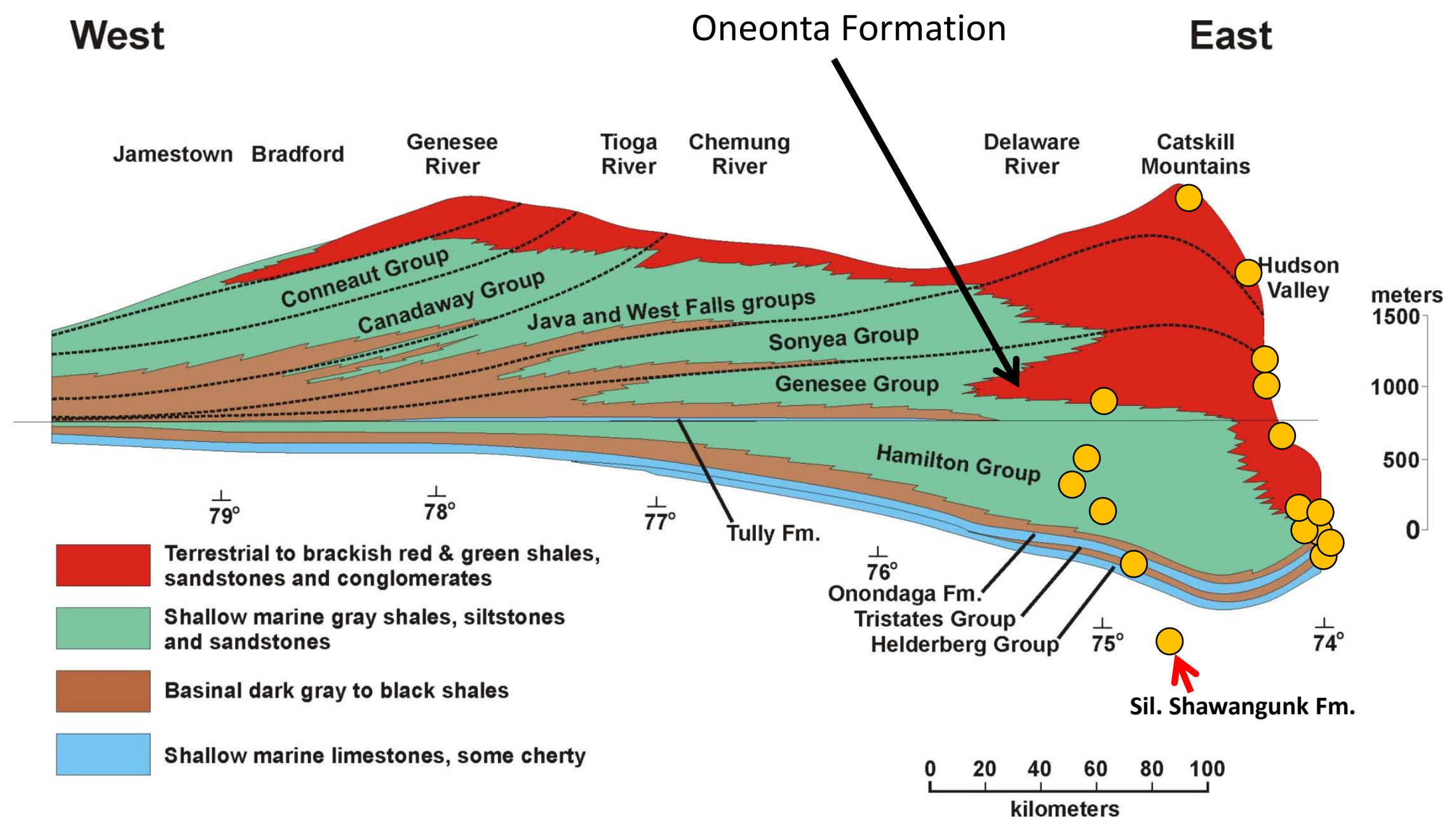




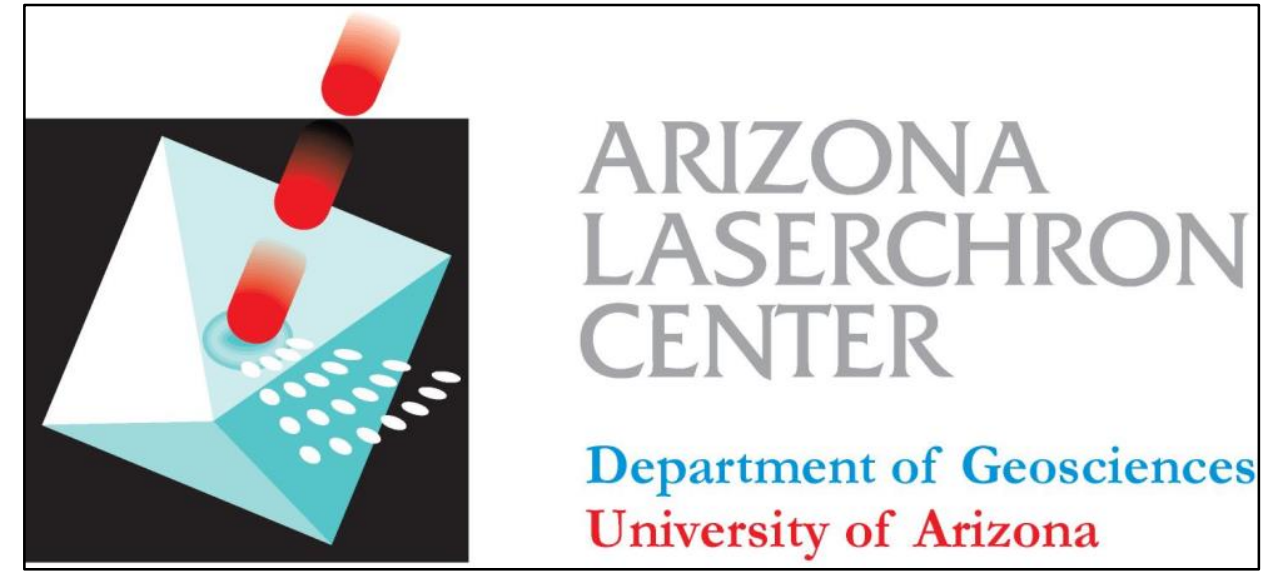

(Many thanks to Mark Pecha, Dominque Geisler, and other staff at the Laserchron Center)
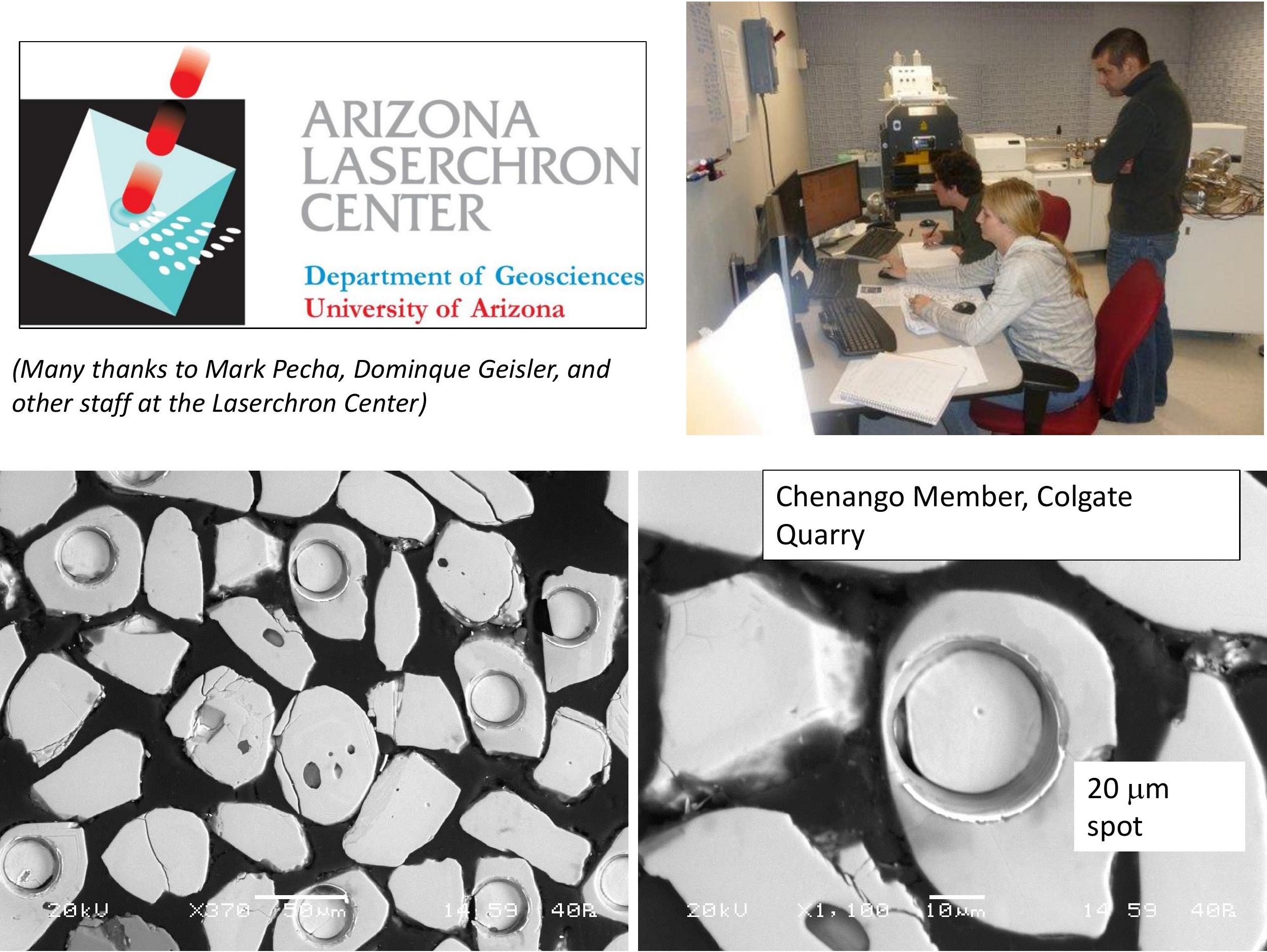


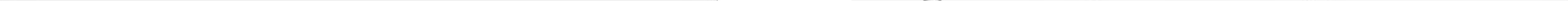




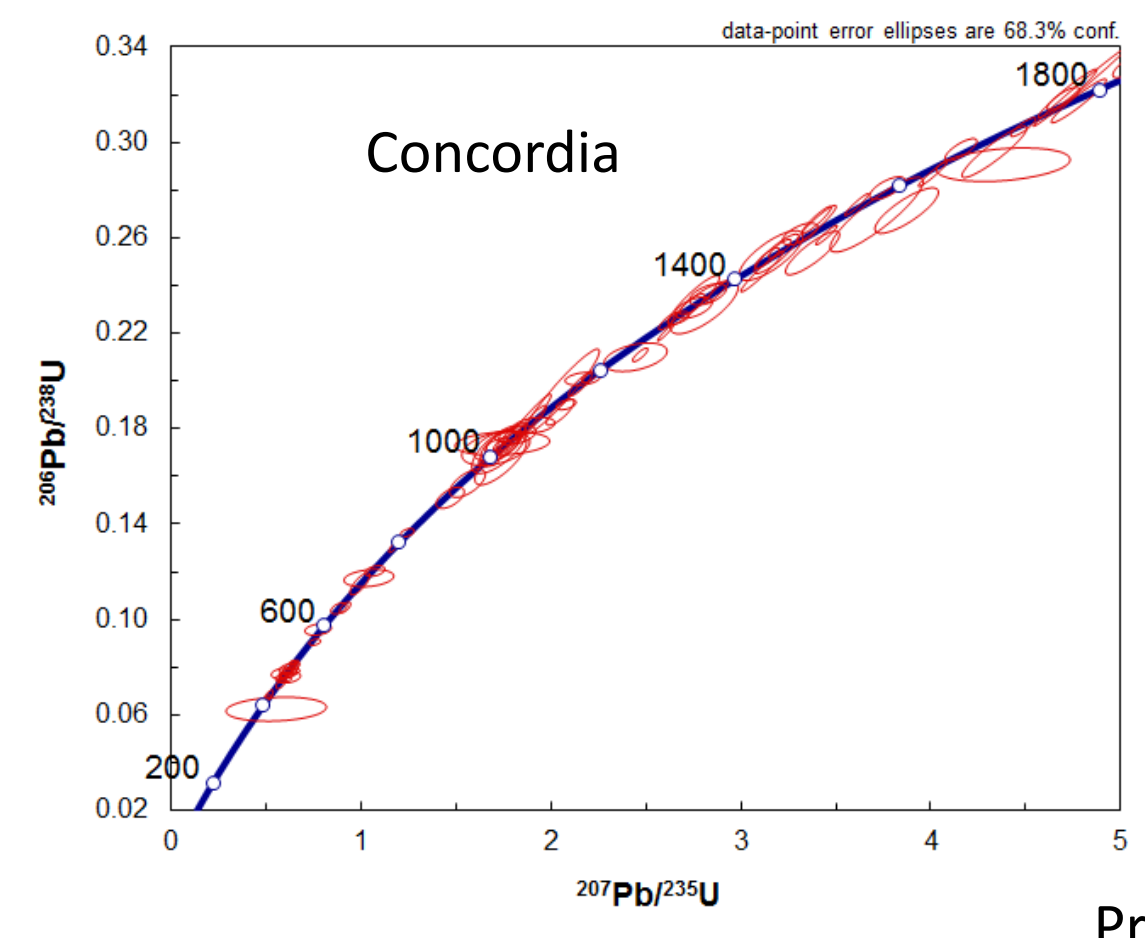

Chenango Member, Skaneateles Formation, Hamilton Group, Colgate Quarry

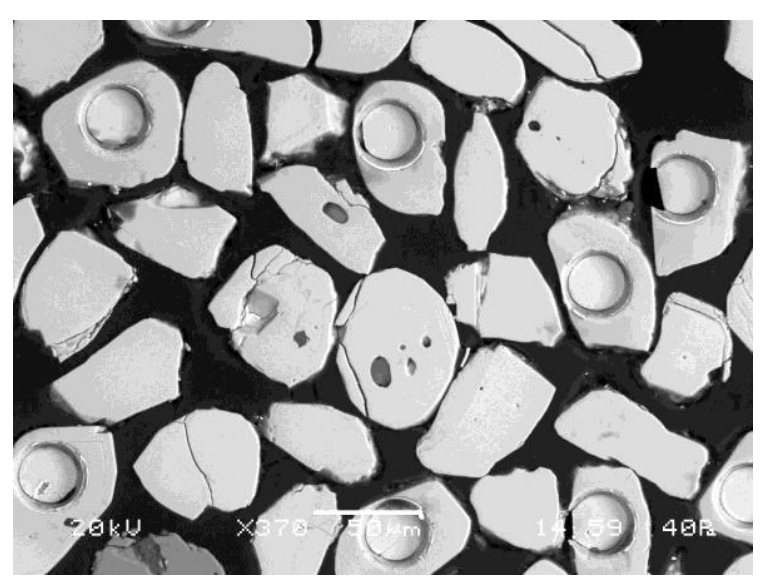

\section{Probability-density}

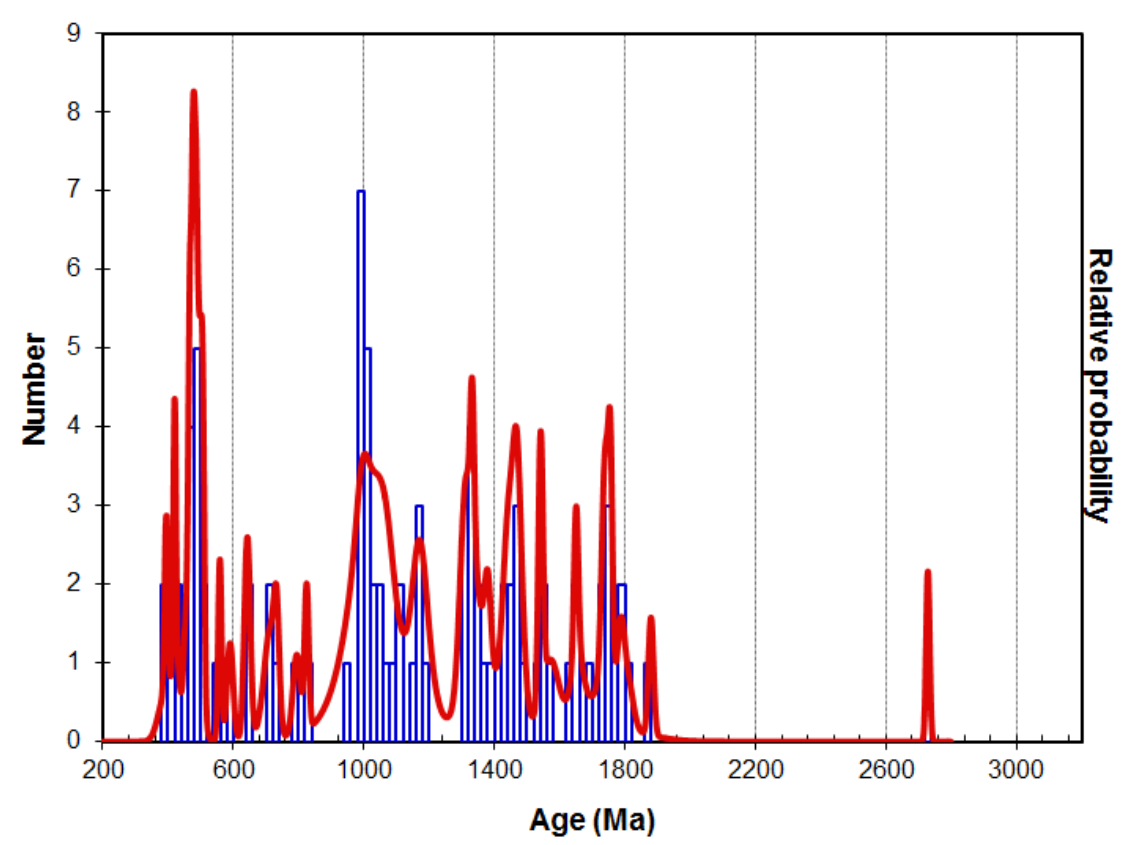

$n-100$ to 300 grains

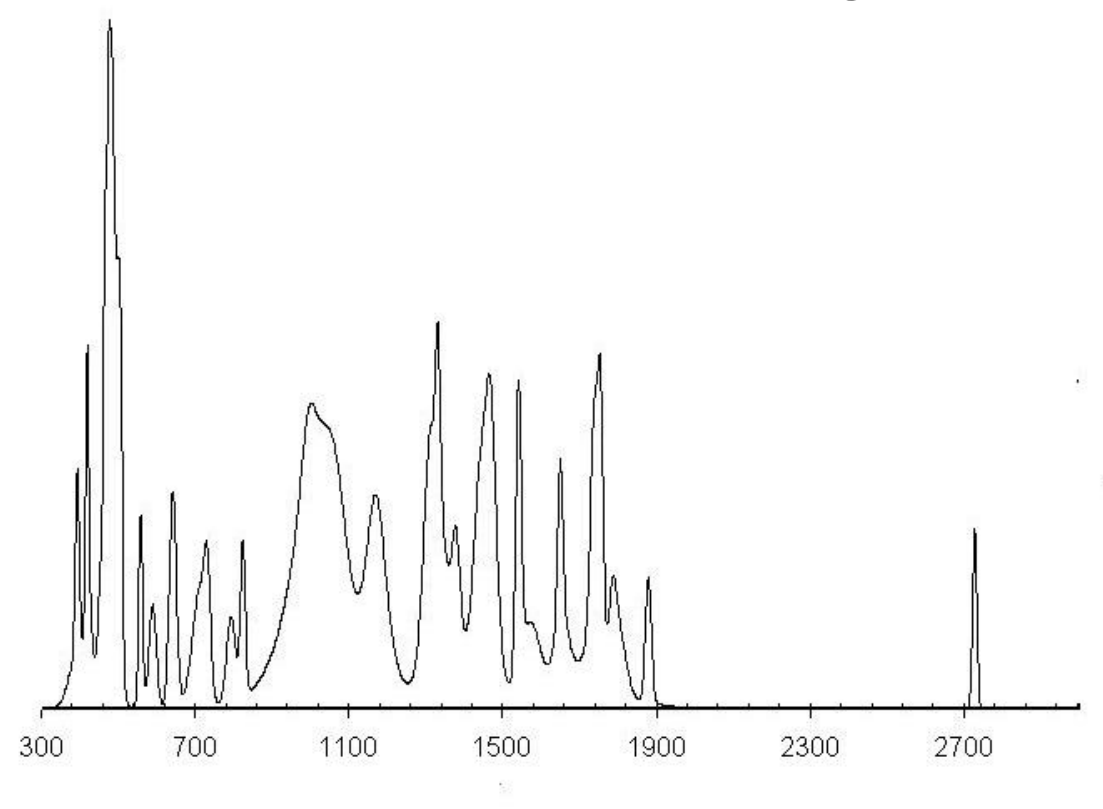




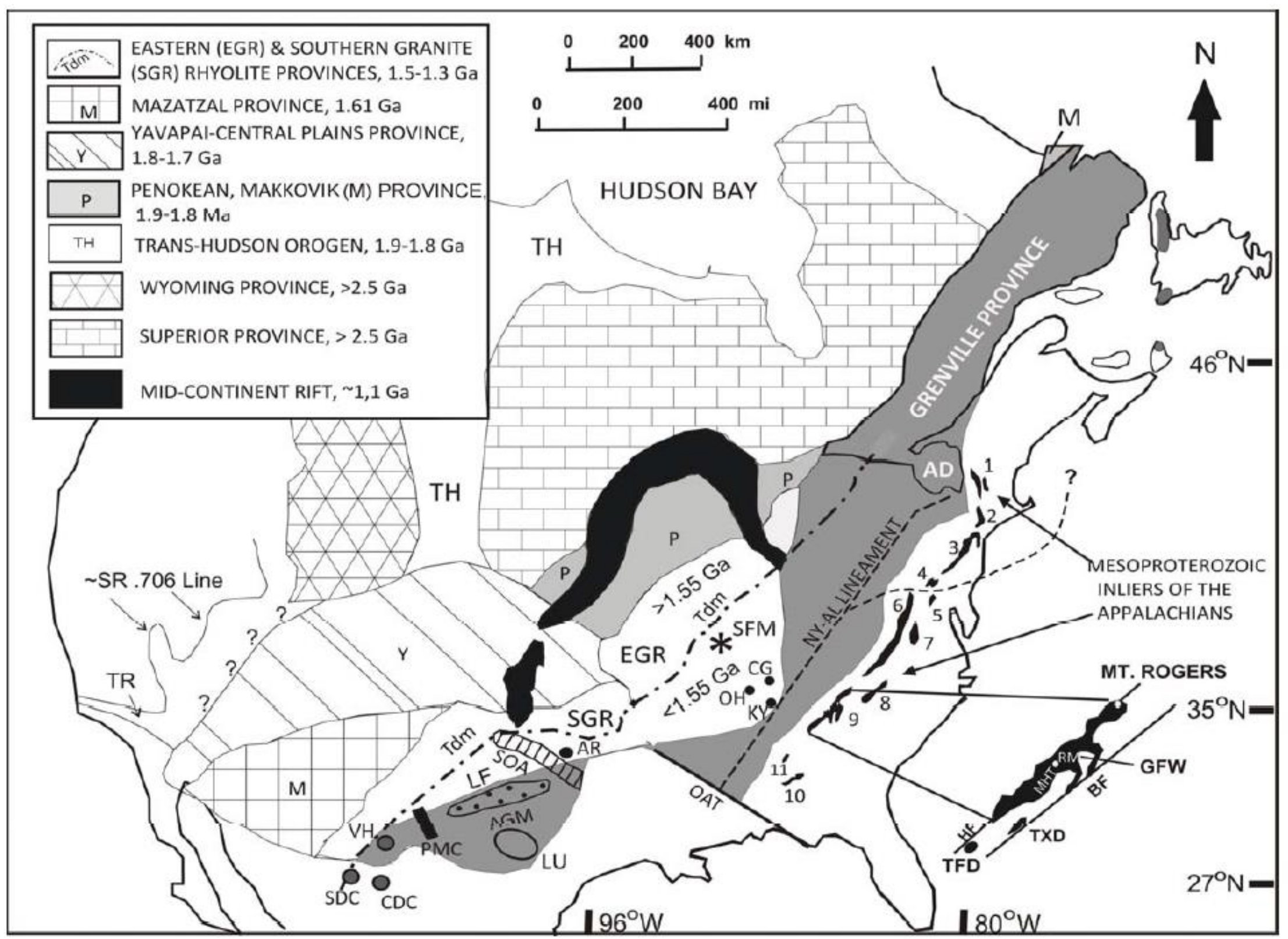

Figure 1. Generalized map depicting major tectonic and geochronological subdivisions in the USA. The Grenville Province is shown in medium gray and its exposed portions are indicated by heavy outlines. Abbreviations: AD = Adirondack Mountains,

(from Tectonic Evolution of the Adirondack Mountains and Grenville Orogen Inliers within the USA, McLelland, et al, 2013) 


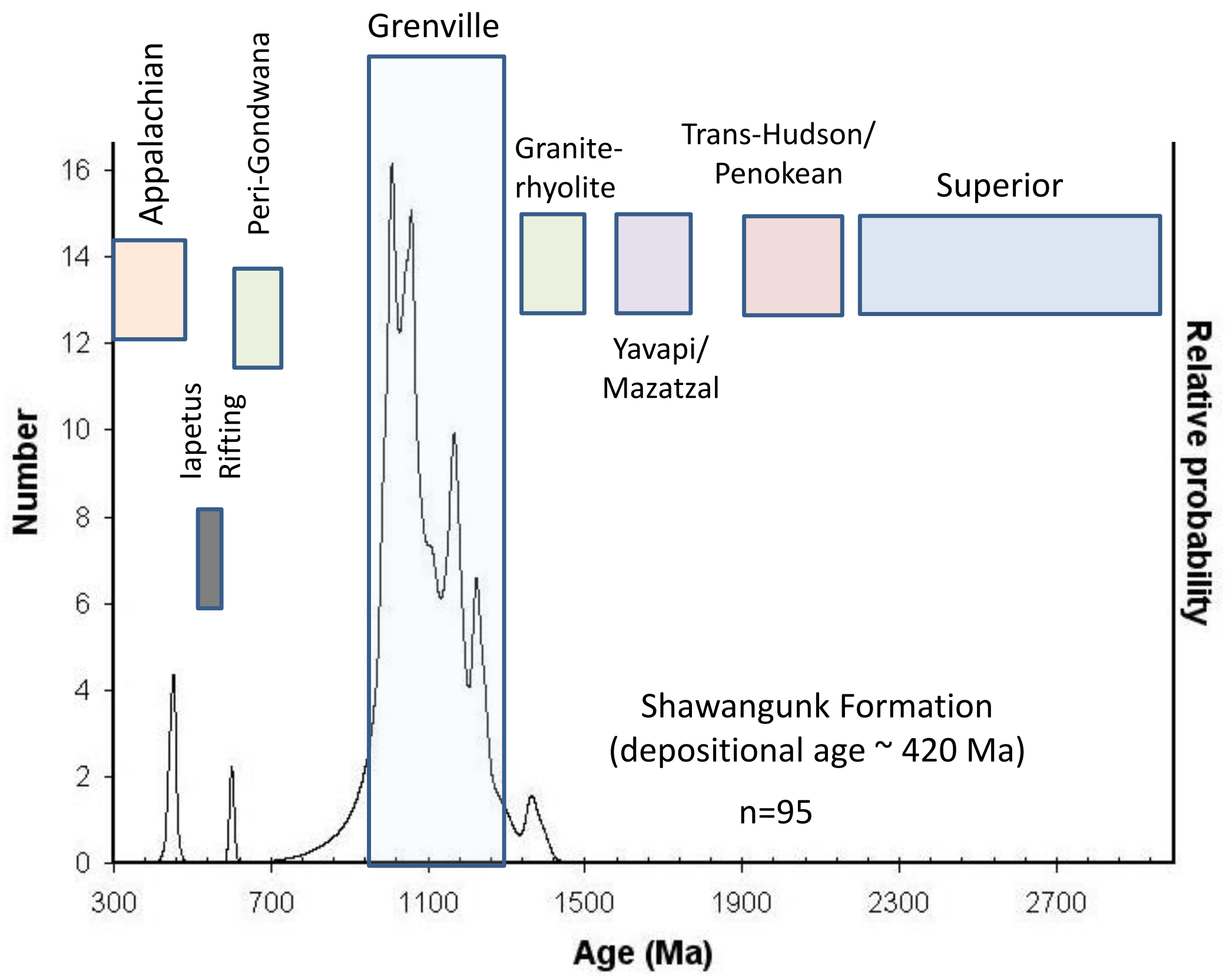



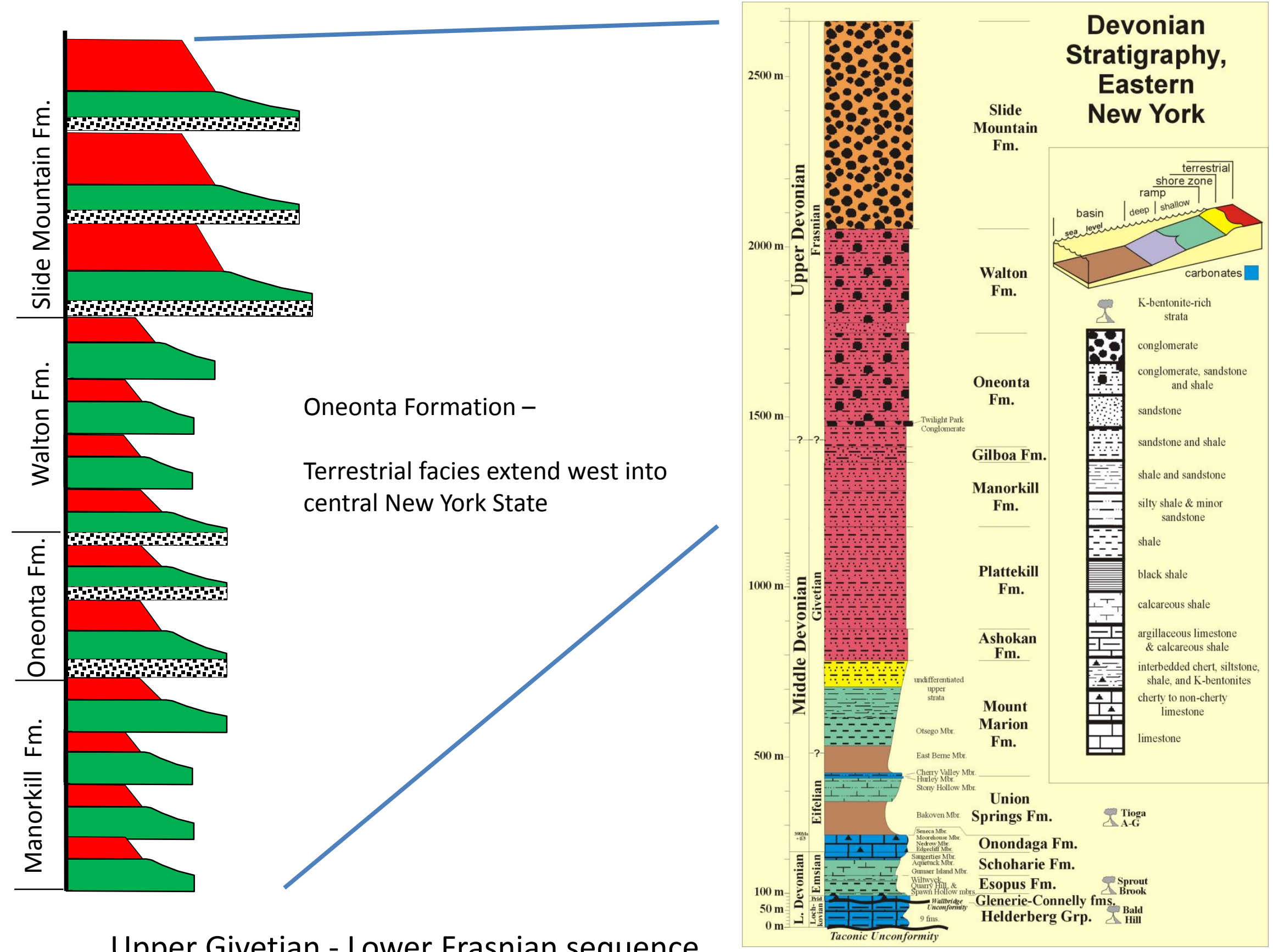

Upper Givetian - Lower Frasnian sequence 


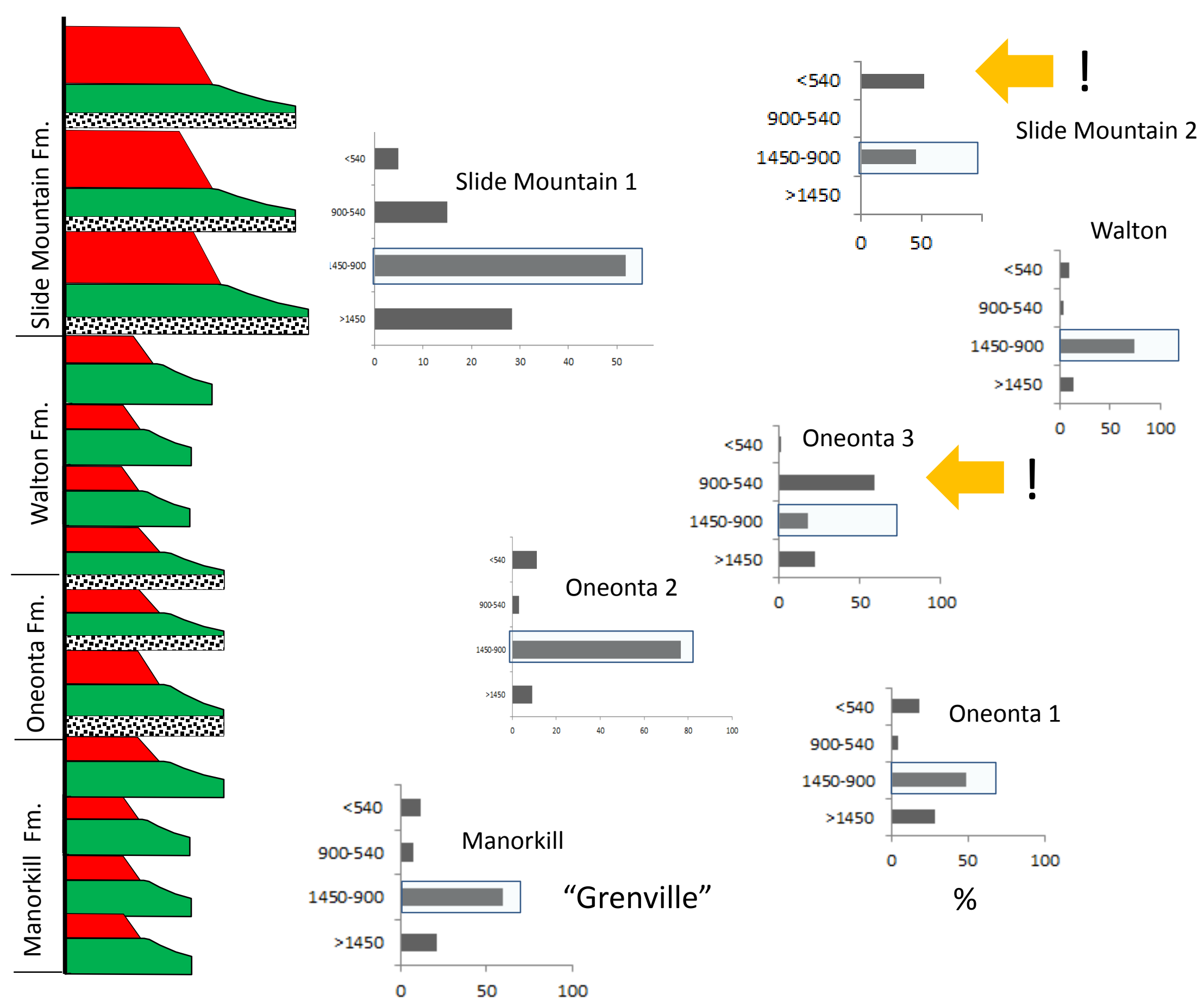




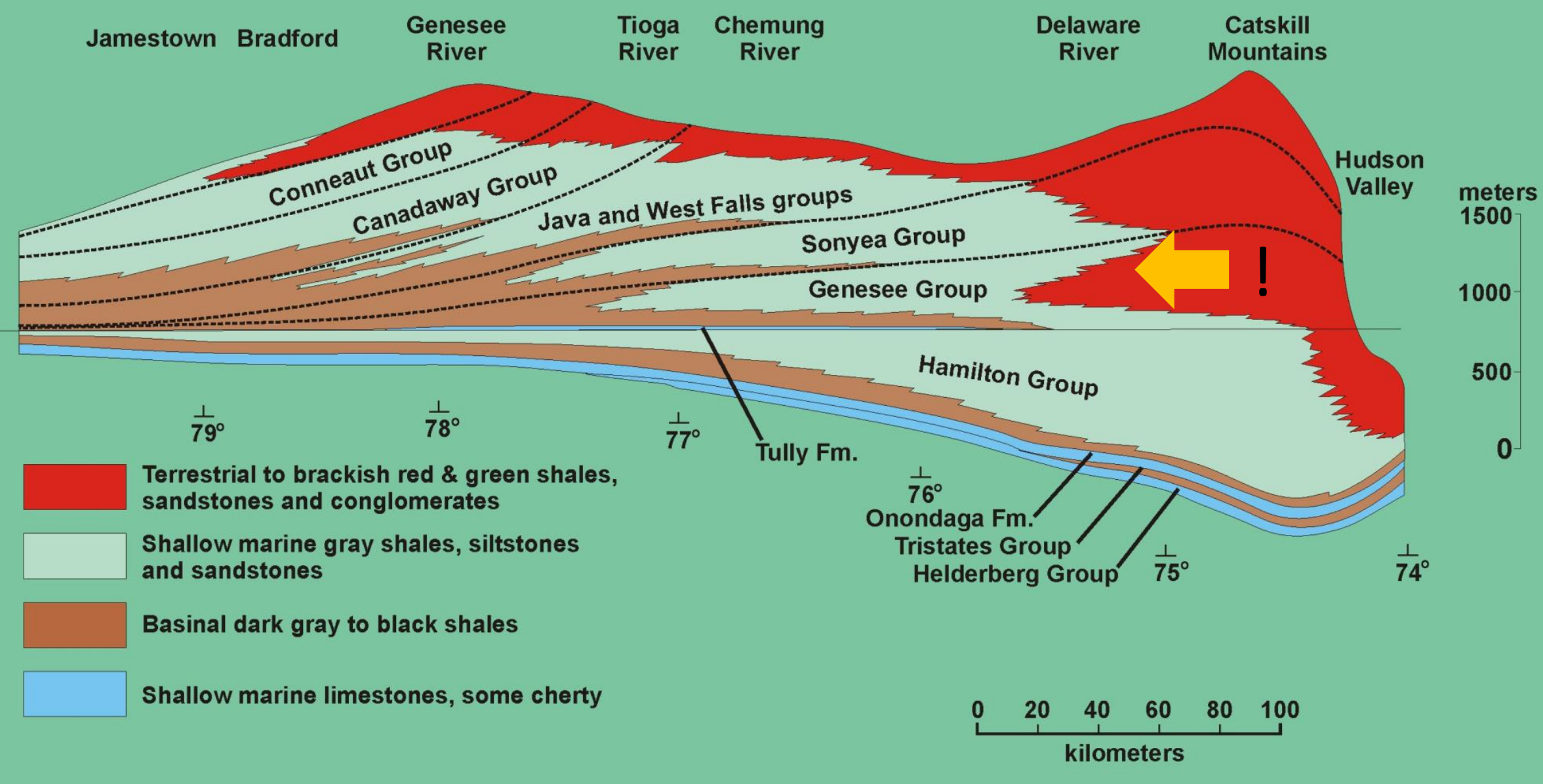




\section{sandstone petrology}

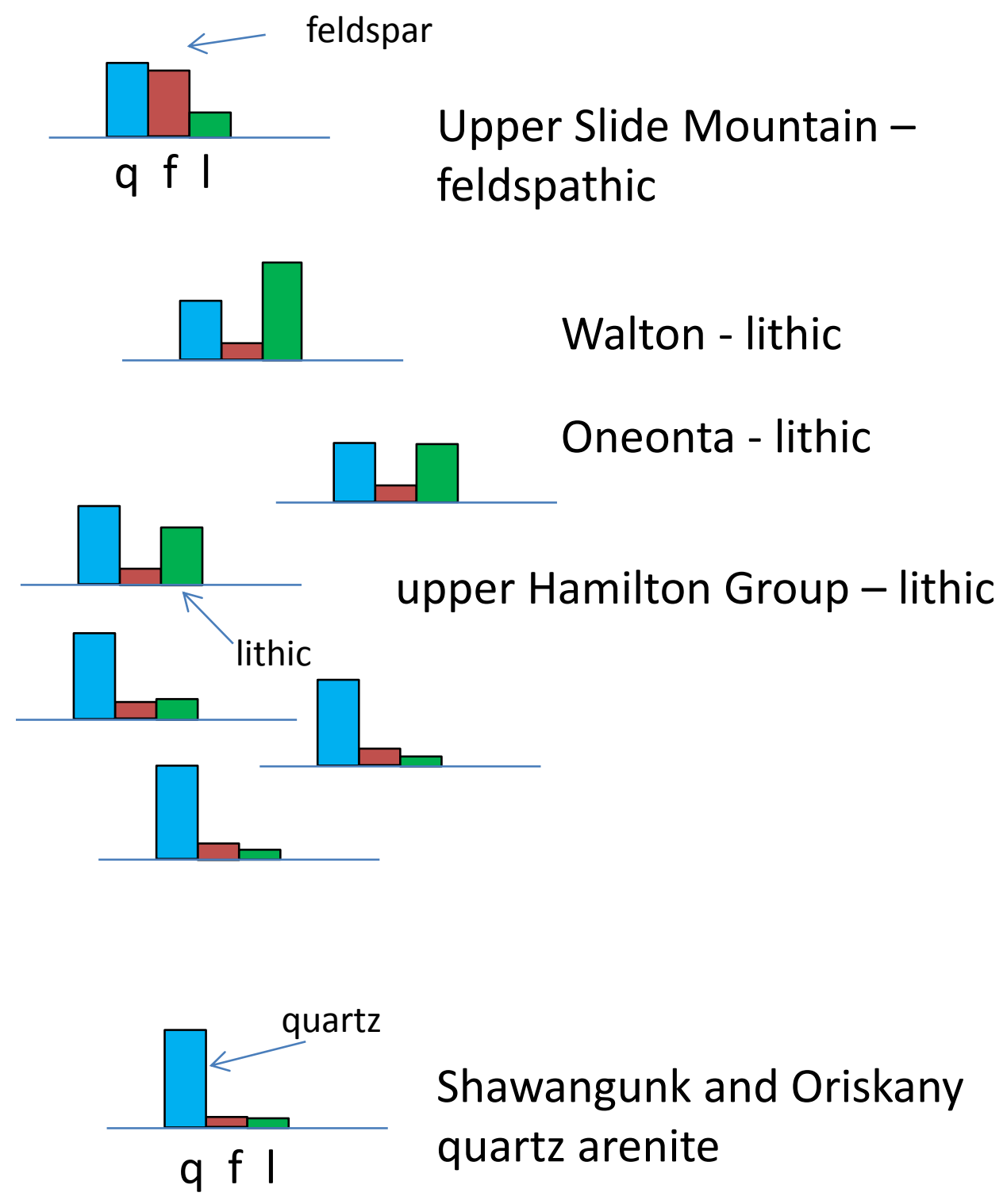

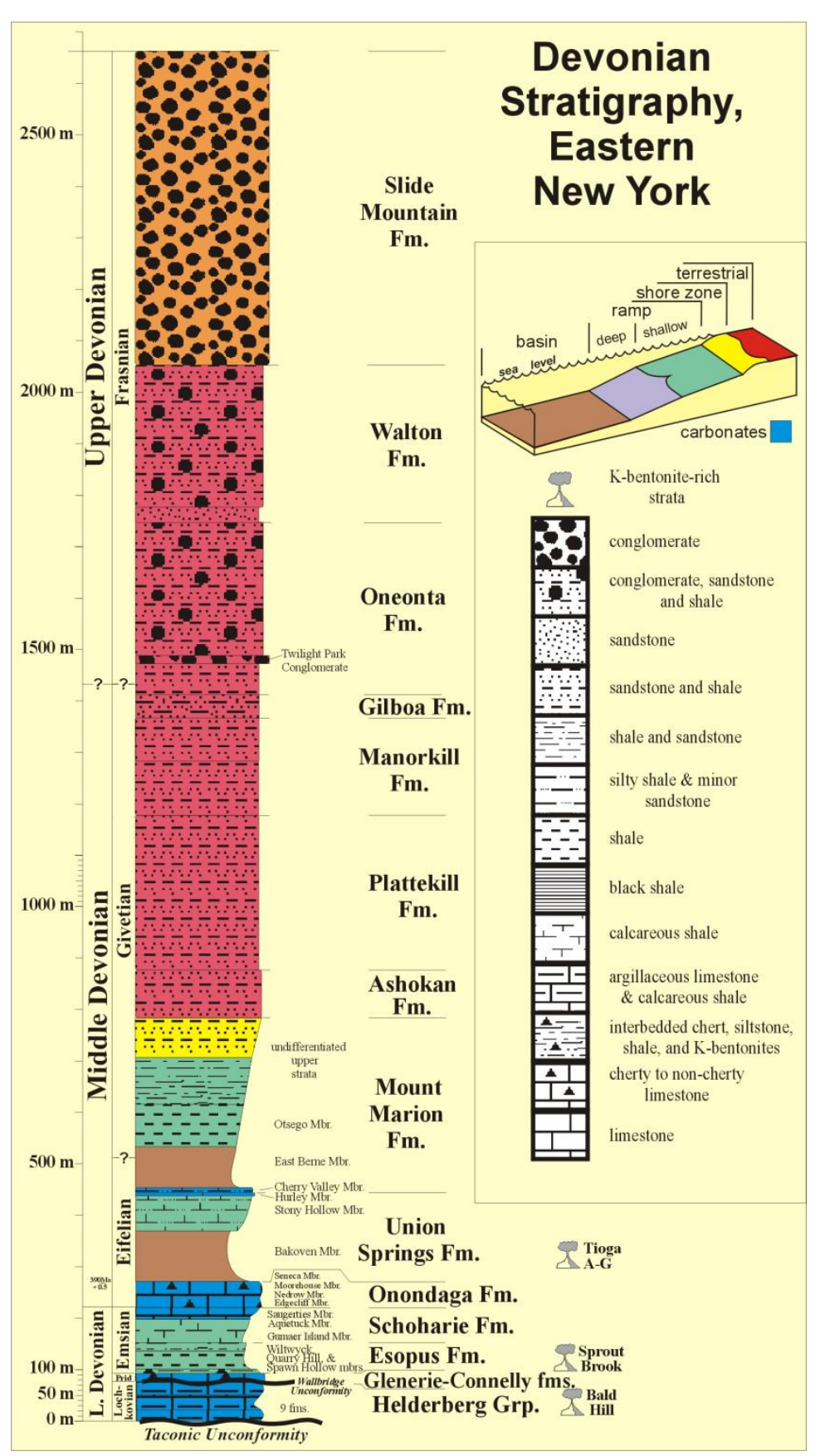


Zircon populations from middle to upper Lower Devonian (Pragian and Emsian Stages) strata are dominated by Grenville (ca. 1400-1000 Ma) and older grains, derived largely from older Paleozoic clastic rocks that were originally sourced from the Laurentian craton.

Lower Middle Devonian (Eifelian to lowest Givetian) siliciclastics, including the Marcellus subgroup, are dominated by Laurentian sources, with younger Grenville (Ottawan, ca. 1080$1020 \mathrm{Ma}$ ) zircons most abundant.

Upper Middle Devonian (Givetian) clastics are dominated by Grenville zircons, but include larger ca. 470-420 Ma populations from igneous and metamorphic sources within the Appalachian Orogen.

Lower Upper Devonian (Frasnian) strata contain zircon suites signaling new source terranes including Neoproterozoic 'peri-Gondwana' (ca. 950-540 Ma) source rocks.

Zircon populations from the lower Frasnian Oneonta Formation document an abrupt shift to a provenance with much greater abundance of Neoproterozoic age materials, likely derived from newly-exposed Avalonian/peri-Gondwanan sources.

The later Frasnian strata (Slide Mountain Formation) contain relatively fewer Neoproterozoic zircons, and increased contributions from Paleozoic igneous and metamorphic sources.

Biostratigraphic/age control in terrestrial facies is less than ideal. Next steps: marine units that are better-constrained. 